\title{
A HISTORICAL ACCOUNT OF THE HYPODERMIC MODEL IN MASS COMMUNICATION
}

\author{
JEFFERY L. BINEHAM
}

This essay examines a dispute over the history of mass communication research by focusing on different accounts of the hypodermic model in mass communication literature. The essay argues that attention to the processes of historiography can help to explain how different conceptions of the hypodermic model, and different conceptions of the field's history, are embraced and articulated. Different conceptions of the history of mass communication research are related to different ideological, theoretical, and methodological commitments. The essay demonstrates that how one articulates the history of mass communication research has significant implications for how one understands and studies the media.

QCHOLARS in mass communication have begun recently to argue over what, at first observation, seems to be a somewhat curious concern: the field's history. In simple terms the argument considers the extent to which the field's received or assumed history is accurate. Advocates for the received view assert that research and theorizing about mass communication have progressed from the powerful mediadirect effects model to a limited effects model that emphasizes intervening variables such as cultural background and personal characteristics. Those who view the media as forces which shape the very ways in which we think and act often appeal to some rendition of the direct effects model as support for their position. From the limited effects perspective evolved the now popular view that the media are but one among many influential forces in contemporary society. Those who dispute this received view argue that the direct effects, or hypodermic, model was never endorsed by early mass communication research, but that it was a theoretical foil invented by those who articulated a limited effects perspective.

This essay examines this battle for the past as a rhetorical confrontation. It sees the argument, in other words, as an effort to define history. At issue then, in some sense, is what it means to study mass communication. The field's typical disputes have considered issues such as how and to what extent the media change people, the nature of that change, the institutional constraints upon media content, and how and to what extent the media hegemonically support the status quo. Participants in such disputes may or may not marshal historical evidence to support their positions, but particular histories are presumed as bases for the different perspectives. The current concern with history itself is, therefore, a significant one.

The importance of this concern, however, is not evident within those essays that deal with the issue. Why scholars bother to examine and "correct" the received history of research in mass communication is strangely unclear. At issue is how to interpret the field's evolution. The interpretation a scholar accepts influences how that scholar thinks about and studies mass communication. This essay's primary concern, then, is to explore different conceptions of the history of mass communica-

Jeffery L. Bineham is an Assistant Professor of Speech Communication at St. Cloud State University. An earlier version of this paper was presented at the annual meeting of the Central States Speech Association, Cincinnati, April, 1986. The author thanks Jennifer Daryl Slack for helpful comments on that earlier version of the paper. 
tion research, and to suggest how these different conceptions both evolve from and encourage different theoretical perspectives toward media studies.

This issue is examined in three sections. Section one briefly highlights the critical endeavors and commitments implicit within the research and writing of history. Section two, which comprises the bulk of the paper, critiques the different historical conceptions of mass communication research. Representative data from original essays is shown to function as support for different interpretations of the historical progression. The design in section two is to understand the different historical interpretations and to suggest why those different interpretations exist. Finally, section three argues that the different conceptions of the history of mass communication research, and of the hypodermic model, influence the theoretical and methodological choices made by mass media scholars. With this framework in mind, let us now discuss the historian's place in the dispute.

\section{WHAT IT MEANS TO DO HISTORY}

History is not 'what happened in the past'; rather, it is the act of selecting, analyzing, and writing about the past. It is something that is done, that is constructed, rather than an inert body of data that lies scattered through the archives. (Davidson and Lytle, 1982, p. xvii)

Davidson and Lytle's penetrating expose on "the art of historical detection" highlights the critical choices essential to the historiographical process and, in so doing, illustrates a conception of history that is embraced by scholars in a variety of disciplines. This conception recognizes that history always involves a historian, and that historians come replete with values, beliefs, and attitudes that are necessarily employed in the interpretive and analytical tasks of research and writing. Interpretation and analysis are not merely accoutrements to the historiographical process. They are not fineries draped across the historical product that shape it in some acceptable way. These critical activities are the essence of history. They are the elixir that infuse data with meaning and thus make history.

The question of any particular history's meaning is best understood in relation to theoretical convictions. A theory, what one posits the world to be like, both describes and explains data. A theory sees some things as important and others as unimportant; it establishes criteria for what constitutes a fact; it describes events and ideas; and perhaps most importantly, it explains what those events and ideas mean. Any historical conception is guided, implicitly or explicitly, by a theory which provides the conceptual categories that render data understandable and meaningful.

While historical accounts are premised upon theoretical convictions, those accounts are themselves arguments for particular theories. Stuart Hall (1983, pp. 81-82) emphasizes that historical associations are important because they connect ideas to "social forces" and thereby render those ideas effective. Though historical associations can be rearticulated to call forth a diversity of theoretical relationships, such rearticulations are difficult to posit persuasively. Once a particular historical description becomes "common sense," it assumes a status that makes it hard to displace. No notion of common sense, however, is irrefutable. The rearticulation of those historical associations which comprise common sense is always a possibility.

Arguments over history, then, are not concerned merely with past occurrences. Of far more importance are the theoretical quarries that are at stake, for with them come the common sense assumptions upon which research and, ultimately, society are based. 
Any account of mass communication research must be seen in light of this conception of history. Characterizations of the field are just that, characterizations. This does not mean that they are false or that all are of equal value. Certainly some accounts are perceived to "report the facts" more accurately than others. The question of "accuracy" remains important, but the pre-eminent issue is what a particular characterization means to its adherents. My concern with regard to the history of research in mass communication is, consequently, not focused upon the "factual" validity of the different positions, but upon the theoretical commitments that sustain those positions. I turn next to an examination of the disparate historical records.

\section{WHICH PATH HAS BEEN TROD?}

In this section I focus on some diverse accounts of how research in mass communication has evolved. I critique historical synopses by DeFleur, Chaffee and Hochheimer, and Wartella and Reeves, and discuss some representative samples of the literature to which these historical synopses refer. My purpose is to show how different assumptions lead to different historical accounts.

The argument under examination centers upon whether or not the received tradition of mass communication research accurately represents the field's development. This disputed tradition is articulated concisely by Gurran, Gurevitch and Woollacott (1982, pp. 11-12). They assert that during the 1920s and 1930s there was widespread agreement "that the mass media exercised a powerful and persuasive influence." This agreement, they state, was premised on four related concepts. First, early researchers thought that technological innovations, coupled with "the mass production of communications," had created a "mass audience": a conglomerate of millions who could now attend to the same message. This audience, secondly, was believed to exist in an urbanized and industrialized society "that was volatile, unstable, rootless, alienated and inherently susceptible to manipulation." These first two concepts were conflated to form the third: The susceptible mass audience was viewed as "easy prey to mass communication." Finally, the idea that people had been "brainwashed" by mass mediated messages during World War I served to validate the first three tenets. This view of the media as an all-powerful and direct influence is commonly titled the hypodermic model of mass communication. And this received tradition is now questioned by several scholars.

During the 1950's and 1960's the hypodermic model was replaced by Katz and Lazarsfeld's (1955) theory of "personal influence." They viewed society "as a honeycomb of small groups bound by a rich web of personal ties and dependencies [that] helped to shield the individual from media influence" (Curran, Gurevitch, \& Woolacott, 1982, p. 12). For Katz and Lazarsfeld, people controlled the media rather than vice versa. Not only was the audience active, but it was heterogeneous. Different members possessed different character traits, lived in different subcultures, adhered to different values, and would therefore, because of these mediating variables, react differently to messages.

According to Gitlin (1978), Katz and Lazarsfeld's limited effects model constitutes the dominant paradigm in mass communication research. Gitlin notes that in articulating this model they "were explicitly aiming to dethrone the 'hypodermic' theory" (p. 210). Others, such as Chaffee and Hochheimer (1985), Wartella and 
Reeves (1982,1985), and Reeves and Wartella (1982), argue that the hypodermic model never existed, but that the notion of the all-powerful media was created by Katz and Lazarsfeld to justify their work and to draw attention to their findings. This disagreement needs investigation, for it has profound implications for how one views the mass media and for how one engages in mass communication research.

Two significant assumptions guide how one reads the field's history. The first concerns where one locates the field's conceptual roots; the second concerns how one conceives of the hypodermic model. Other influential assumptions are made, of course, but attention to these two can heighten our understanding of the divergent positions.

\section{The Origins of Mass Communication Research: Mass Society Theory}

In the early days of communication study, the audience was considered relatively passive and defenseless, and communication could shoot something into them. (Schramm, 1971, p. 9)

Though Schramm emphasizes the final phrase of this quotation, my concern is with the initial one: What are "the early days of communication study"? Very different answers to this question can be found.

As early as 1966, DeFleur endeavored to demonstrate how sociologists writing about mass society wielded a decisive influence upon early thinking about the effects of mass communication. ${ }^{1}$ DeFleur (1966, pp. 99-102) begins with Auguste Comte, who during the 1830's articulated his view of society as a "collective organism" (Comte, 1915). Comte anticipated that as society urbanized and industrialized, its increasing emphasis on specialization could lead to a stable and orderly system. He was not entirely optimistic about the prospect, however, for he saw in specialization the temptation to over-specialize, and to forsake individuality for compliance to the uniform system. Comte represented a body of scholars who abjured the possibility of movement toward what later came to be known as "mass society," and thus advocated social controls upon society's development. Social Darwinists like Herbert Spencer (1969), who originally wrote in 1863 , also saw society as an organism engaged in a process of specialization, but they viewed this as a natural evolutionary phenomenon that should not be disrupted (DeFleur, 1966, pp. 102-103). Though Comte and Spencer had different attitudes toward social change, they shared the notion that society was becoming more specialized.

This concept of specialization was the precursor to Ferdinand Tonnies' (1957) assessment of Gemeinschaft and Gesellschaft in 1887. In simple terms, Gemeinschaft represents a form of social order based on interpersonal relationships within a specific community. In Gesellschaft people become dependent upon others whom they do not know; hence there is need for social contracts to ensure that agreements and responsibilities are kept. The dependence upon contracts introduces a formal, impersonal element into social relations.

The move to industrial society was, for Tonnies, a move to Gesellschaft, and the result, in his words, was that "everybody is by himself and isolated" (DeFleur, 1966, p. 106). Gesellschaft "places the individual within a social system that is impersonal and anonymous" (p. 106). Tonnies, in many ways, justified Comte's fear of overspecialization, and this concern was echoed by Emile Durkheim in 1893. Durkheim's (1933) concepts of mechanical solidarity and organic solidarity correspond, respectively, to Gemeinschaft and Gesellschaft, and he too saw society moving 
toward the formal impersonality of the more specialized system. The bond of common values that marked Gemeinschaft, or mechanical solidarity, had been disrupted by the move toward an urban, industrial, and impersonal society.

DeFleur (1966) writes that the social trends stressed by Comte, Spencer, Tonnies, and Durkheim led to a concept of mass society that strongly influenced early theorists of mass communication. That concept of mass society was marked by:

an increase in heterogeneity and individuality, a reduction in the degree to which society could effectively control its members through informal means, an increasing alienation of the individual from strong identification with his community as a whole, a growth of segmental, contractual social relationships, and a great increase in the psychological isolation of the human being. (p. 111)

This idea of mass society is identical to Katz and Lazarsfeld's (1955) conception of the "atomistic mass" which, they said, described the early studies' view of mass communication's audience (p. 16). The depiction of mass society by these early sociologists convinced people that it was possible for this large but isolated population to be uniformly manipulated by an appropriately designed and delivered message. Even before the turn of the century Gustave Le Bon was to assert that the "mental unity" of a crowd rendered it susceptible to mass hypnosis.

Le Bon (1952) argued that in a crowd "the sentiments and ideas of all the persons in the gathering take one and the same direction, and their conscious personality vanishes" (p. 23). Such a state, to be sure, established the conditions necessary for a hypodermic theory of communication. When in a crowd the individual feels invincible; every sentiment, every act, is widely contagious as personal values and goals are sacrificed for those of the group. As the conscious personality and critical faculties of individuals are displaced, the crowd is left to the whims of the "hypnotist," whose suggestions are uncritically transformed into acts (pp. 30-31). Even the most cultivated individual, once in a crowd, becomes a "barbarian," a "creature acting by instinct" who can be "induced" to act without regard for his or her best interests (p. 32). A suitable dispatch, Le Bon assumed, could control the mass.

Le Bon was not alone in his assessment. Wilfred Trotter's 1916 text, Instincts of the Herd in Peace and War, emphasized the importance of gregariousness in human activity. People, Trotter argued, are comfortable only in a group, and he believed, like Le Bon, that this fostered an imitative and potentially irrational credulity which created, in turn, the propensity to accept suggestions uncritically. Indeed, in a mass society "suggestibility" is a normal quality of the human mind, and suggestions have the force of instincts (see Trotter, 1942, pp. 20-33).

Terms such as "herd" and "instinct" were also part of the scientific behaviorism that DeFleur says influenced early mass communication research. John B. Watson, that quintessential behaviorist, asserts the irrelevance of terms such as "consciousness," "mental states," "imagery," and "mind" that would later represent mediating or intervening variables. The focus of study should be habit formation and the determination of behavior, and that study should be conducted within a stimulusresponse framework (1913, pp. 166-167). "Basic human nature," writes DeFleur (1966, p. 116), "was thought to be fairly uniform from one human being to another." This belief, combined with the mass society concept, led eventually to the hypodermic theory. 


\section{The Hypodermic Model's Influence on Mass Communication Research}

Pro-hypodermic scholars, like DeFleur, argue clearly that early mass communication research was influenced significantly by nineteenth century European social theory. ${ }^{2}$ Hall (1982) notes that the pessimistic view of mass society was distinctively European, and that this view was influential in the United States as well. And Rowland (1983), who refutes the received history, does state that mass communication "was an aspect of the arrival of the social and behavioral sciences," and he remarks that those sciences were "infused at the outset with a certain element of the theoretical concerns of European social philosophy" (p. 52). The pro-hypodermic position is based upon the presumed influence of the European mass society theorists discussed above.

That influence, however, is not obvious, and its very presence is questioned by anti-hypodermic scholars. The influence goes unnoticed, in part, because it is presumed by the received history and thus frequently left undemonstrated. Cressey, for example, asserts that prior to the Payne Fund studies, students of motion picture influence disregarded "the social background and personal interests of their subjects," made "sweeping statements about the motion picture's effect," and argued "that young people who see 'undesirable', 'immoral', or even criminal conduct upon the screen will go out and do likewise, or at least tend inevitably to acquire corresponding attitudes and values" (1938, p. 518). While Cressey describes the influence of mass society theory, and articulates a clear hypodermic model, he does not identify those early students of motion pictures to whom he refers.

A second example of this difficulty is Bauer and Bauer's (1960) assessment of the interface between mass society theory and mass media research. They argue that "the 'theory of mass society' must, by virtue of its provocativeness, the articulateness of its supporters, and its prevalence among intellectuals, be taken as the point of departure in a discussion of the role of the mass media in America" (p. 4); and they assert that prior to World War II scholars presumed a "one-to-one relationship" between media content and public effect (p. 7). Like Cressey, Bauer and Bauer conduct their discussion with few references to specific mass society theorists and, maddeningly, they cite no one who is typically considered to be a mass communication researcher.

Adherents of the pro-hypodermic view can point, nevertheless, to several studies which do illustrate the influence of both mass society theory and the hypodermic model. Many of the emphases discussed in the preceding section of this paper are evident in Harold Lasswell's significant 1927 work, Propaganda Technique in World War I. Delia, though he advances an anti-hypodermic view, writes that Lasswell's work can be read "as an undifferentiated and direct-effects conception of mass communication" (1987, p. 26). Lasswell, widely cited as one of the fathers of mass communication research, asserted that the propagandist's task "consists principally in selecting the social suggestions best calculated to evoke the desired response" (1970, p. 195). That desired responses could be uniformly evoked was seemingly self-evident. Because the industrial society had produced "an atomized world," propaganda could "weld thousands and even millions of human beings into one amalgamated mass of hate and will and hope" (pp. 221-222). According to proponents of this pro-hypodermic view of mass communication history, the media were seen during World War I as omnipotent forces that wielded direct, unmediated 
influence upon a passive and unsophisticated audience. DeFleur, writing with Ball-Rokeach (1982), states this view succinctly:

[In the years surrounding World War I, mass communication theory] assumed that cleverly designed stimuli would reach every individual member of the mass society via the media, that each person would perceive it in the same general manner, and that this would provoke a more or less uniform response from all. (p. 106)

DeFleur and Ball-Rokeach are careful to note that this hypodermic model was never systematically articulated by any early communication scholar (p. 161). The concept, however, was dominant. Every audience member was believed to receive media messages in a uniform way, and those messages provoked a direct and immediate response.

Pro-hypodermic historians interpret the Payne Fund studies in similar fashion. Tudor (1974) writes that mass communication's classical works can be compressed "into the simple image of the hypodermic" (p. 29), and that "the ultimate problem of the Payne Fund Studies is . . their largely hypodermic model of the communication process" (p. 94). Kindem and Teddlie (1982) assert more specifically that Thurstone's Payne Fund experiment "either implicitly or explicity reinforces the hypodermic theory of mass-media effects" (p. 198). While some of Thurstone's reports do account for intervening variables (see Lowery \& DeFleur, 1988), his initial publication (1931) contains no mention of variables such as social, economic, cultural, or intellectual background, but asserts that the film "Street of Chance" "quite evidently had the effect of making the children regard gambling as a much more serious offense than they did before seeing the film" (p. 297). He concludes simply "that motion pictures can be used to affect the social attitudes of school children and that these effects can be objectively measured" (p. 304). Thurstone's study does illustrate a hypodermic model of the mass communication process.

Freidson (1954), Tudor (1974), and Rowland (1983) also cite Blumer's Payne Fund study for its assumption of "a direct media-stimulus to audience response process" (1983, p. 94). Blumer's 1933 text entitled Movies and Conduct concludes that a movie viewer "loses himself" in the drama and "becomes malleable to the touch of what is shown. Ordinary self-control is lost. Impulses and feelings are aroused, and the individual develops a readiness to certain forms of conduct which are foreign in some degree to his ordinary conduct" $(1970$, p. 198). This description of motion picture effects presumes the tenets of the hypodermic model. Media content delivers a general and undifferentiated direct influence upon its audience. The very title of Blumer's 1936 publication, "The Moulding of Mass Behavior Through the Motion Picture," indicates continued adherance to the hypodermic model's basic premises.

One final example cited by pro-hypodermic scholars (see Coser, 1960) is Merton's analysis of a Kate Smith war bond drive. Merton's opening paragraph reflects the assumptions of the hypodermic model:

But never before the present day has the quick persuasion of masses of people occurred on such a vast scale. The trivial and the large decisions alike are made the object of deliberate control. Large populations are brought to prefer a given brand of soap or hair tonic or laxative. Or, predisposed by their conditions of life, Iarge masses are persuaded to follow a political leader who means many things to many men. Loyalties are captured and control of mass behavior temporarily ensured. Masses of men move in paths laid down for them by those who persuade. (1946, p. 1) 
Merton does discuss intervening variables such as listener predisposition and the social and cultural contexts of the message, and he concludes that Smith's radio campaign exemplifies persuasion rather than propaganda because she was able to approximate "face to face discussion," but he also notes that this is "ordinarily impossible for such an impersonal, mass medium of communication as the radio" ( $\mathrm{p}$. 39). Whatever his findings, Merton's study is motivated by an initial belief in the hypodermic model of mass communication. The media are presumed to deliver messages which provoke direct, immediate, and uniform responses from mass audiences.

The evidence gathered in the last few pages certainly seems to support a pro-hypodermic conclusion. Katz and Lazarsfeld, evidently, had ample data upon which to assert that early research described "the omnipotent media, on one hand, sending forth the message, and the atomized masses, on the other, waiting to receive it-and nothing in-between" (1955, p. 20). The message, they wrote, was pictured "as a direct and powerful stimulus to action which would elicit immediate response" (p. 16). If one traces mass communication theory and research through mass society theorists such as Comte, Spencer, Tonnies, Durkheim, Le Bon, and Trotter, and through mass communication scholars such as Lasswell, Thurstone, Blumer, and Merton, one finds a fairly clear picture of an unmediated effects, hypodermic model of communication.

\section{The Origins of Mass Communication Research: An Alternative View}

The received view of the history of mass communication research does not go unquestioned. Chaffee and Hochheimer (1985, p. 289) argue strenuously that the hypodermic model described by Katz and Lazarsfeld misrepresents the field's history, indeed that it was created as a foil "against which the limited effects model could be contrasted." Early studies, they state (p. 289), "stressed that media impacts are contingent on personal orientations and accordingly differ from one person to another." Wartella and Reeves (1982, 1985; and see Reeves \& Wartella, 1982), similarly, argue at length that the hypodermic model was not a part of the early studies. These scholars assert that the historical data simply do not indicate a hypodermic model. ${ }^{3}$ Why this significant disagreement with the record presented above?

One fundamental reason is that, in their accounts of the field's origins, Chaffee and Hochheimer, and Wartella and Reeves consider different data than do DeFleur and others who accept the received tradition. Chaffee and Hochheimer (1985, p. 267), for example, begin their account of mass communication history with Lazarsfeld's 1944 publication, The People's Choice. In their search for the first significant mass communication theory, they assume the field's origins to be in a far different epoch than that of Comte, Le Bon, or even Lasswell.

Given this assumption, they argue logically that the limited or mediated effects model has always governed the theoretical underpinnings of mass communication. Chaffee and Hochheimer see The People's Choice, Berleson's Voting, and Klapper's The Effects of Mass Communication as the field's classic works (p. 270), and they generalize that, for Klapper, "the impact of mass media on public attitudes and behaviors, especially those in the political realm, should ordinarily be expected to be minimal" (p. 287). Klapper's work, then, discounts the hypodermic model. The 
choice of this evidence stems from a particular interpretation of where the field's roots lie. For while some, such as Schramm (1983), identify Lasswell as a "founding father" of mass communication research, Klapper ignores Lasswell in his summaries of effects research (Delia, 1987, p. 28). Chaffee and Hochheimer (p. 285) follow Klapper's lead when they write that although Lasswell might have presumed a hypodermic model, he did not influence early mass communication effects research.

Reeves and Wartella (1982) imply that their anti-hypodermic interpretation of the field's history hinges on a distinction between mass communication theory and the sociological theories cited by DeFleur:

We are prone to conclude that psychological research on media and youth ... has moved from direct to indirect to middle-ground theories even though the evidence for that conclusion is taken largely from sociological theories about politics and mass society. (p. 4, emphasis added)

Their strong connotation is that such sociological theories should neither be accorded status in the field of mass communication, nor considered in an account of its history. Their refusal to consider this evidence in their examination of mass communication research reflects assumptions and critical choices that help to explain the different historical accounts. Reeves and Wartella explicitly recognize the importance of such assumptions and choices when they note that history is always written from a "particular vantage point," and that "our revision is premised on a particular stance in the current social science milieu" (p. 5).

Those who dispute the existence of a hypodermic model tend also to focus on empirical studies. Wartella and Reeves (1982) note that "empirical studies of media effects on children ... do not fit the received view of American mass media effects history" (p. 3; also see Wartella \& Reeves, 1985, pp. 120-121). Chaffee and Hochheimer (1985) echo that "no empirical study has, to our knowledge, ever purported to demonstrate a universal, massive pattern of media impact" (p. 289). They argue, as well, that "the basic paradigm" for research in "mass communication in political processes" is inherited from "the earliest major studies conducted in the United States" (specifically, Lazarsfeld's), which established "an image of the 'limited effects' of the mass media in the context of election campaigns" (p. 267). Chaffee and Hochheimer note that these "original studies" found limited effects primarily because they "were highly empirical" and assumed "a 'marketing' orientation"; nevertheless, "the idea of 'limited effects' was extended to the entire range of mass communication" (p. 263). Both sets of authors cite the Payne Fund studies, all but one of which were empirical, as examples of early research that does not support a hypodermic model rendition of the field's history.

A reliance upon empirical data, as Gitlin (1978) notes, directs attention toward "the search for specific, measurable, short-term, individual, attitudinal and behavioral 'effects' of media content" (p. 207). Such an emphasis favors data which support a limited effects model, and ignores data which corroborate the hegemonic power of media to influence public opinion (Gitlin, 1978, pp. 205, 207). The findings cited by Chaffee and Hochheimer, and Wartella and Reeves, are implicit in their choices and interpretations of evidence.

Gertainly problems exist with both of the accounts discussed in this section. The pro-hypodermic view attributed to DeFleur, and to Katz and Lazarsfeld, also is guided by its choices and interpretations of evidence, and it fails to consider the influence of the Chicago School upon mass communication research. ${ }^{4}$ Scholars like 
George Herbert Mead (1934) and John Dewey $(1929,1946)$ advanced theories of communication which opposed the stimulus-response framework of the hypodermic model. Though influenced by mass society theorists, they believed that the media were not inherently evil manipulative devices, but that they could revive an informed public opinion and revitalize a sense of personal and social responsibility. This emphasis is unfortunately ignored in favor of a pessimistic mass society theory which depicts the media in an entirely fearful fashion.

The anti-hypodermic view can be cited for at least two weaknesses. First, its basis is the notion that Katz and Lazarsfeld created the hypodermic direct effects model as a foil against which to pit their limited effects theory. But before the publication of Personal Influence, Friedson (1954) argued persuasively against the concept of a mass audience subject to direct effects. And even more significantly, Cressey (1934), writing ten years before the publication of The People's Choice, interpreted the Payne Fund studies to refute a direct effects model of mass communication. For Cressey to address the direct effects concept meant that it had to have existed before Lazarsfeld and his contemporaries posited their limited effects model.

Proponents of the anti-hypodermic view have also cited studies without regard for their influence. Reeves and Wartella (1982), for example, state that "the [received] histories all depend on a small number of seminal works in mass communication as evidence for shifts in research," and they note that Lasswell and Lazarsfeld are used to prove the received view regardless of what other essays might have stated (p. 5). This concern highlights the importance of the criteria by which one selects evidence. In constructing a history one should look primarily to those sources deemed to have been most influential. An assessment of mass communication research ought to identify the people, ideas, and essays which have guided the field's progression. Yet Reeves and Wartella seem to denigrate the influence of Lasswell and Lazarsfeld in favor of more "questionable" evidence. After they have asserted, for example, that a hypodermic model was not advanced by early research, they argue against the idea that the 1930s and 1940s were a period of indirect effects by noting that Frederick Meine, in 1941, "found a 'direct' relationship between children's consumption of newspaper and radio news, and knowledge about current affairs" (p. 13; also see Wartella \& Reeves, 1985, p. 123). Though they cite four other studies that found "direct effects" with adult respondents, they make no mention of these studies" significance, or of the influence they had upon the field. Further, if a hypodermic model never existed, where was Meine's notion of direct effects acquired?

These difficulties are products of the historiographical process. They ensue from the assumptions, hypotheses, inferences, and commitments that lead one to select certain pieces of evidence and ignore others. These value orientations, unfortunately, are often unclear in the historical accounts themselves. The significance of where one locates the field's origins becomes more apparent upon examination of the evidence shared by the different positions. That evidence reveals markedly different conceptions of the hypodermic model itself.

\section{Conceptions of the Hypodermic Model}

To this point I have assumed a rather general notion of a "hypodermic" theory or model. That term's meaning, however, is by no means transparent. Indeed, its ambiguity is a central factor in many attempts to delineate what mass communication scholars should study. 
The use of the term hypodermic is, of course, the transfusion of a medical term into mass communication parlance. A hypodermic needle is a tool for inducing medication directly into the body. The extent to which the effect of that stimulus is uniform among its recipients is the focal point of much scholarly debate. Let us begin an assessment of the different stances by noting a complaint voiced by the antihypodermic school.

Chaffee and Hochheimer (1985) disregard the hypodermic model, and the received history it represents, because the "earliest studies" recognized that media effects were dependent on "personal orientations" and would "differ from one person to another" (p. 289, emphasis added). Wartella and Reeves reach the same conclusion on the basis of several studies which they state "acknowledged individual differences" in response to the media. They cite Dysinger and Ruckmick, for example, to assert that because children of different ages reacted differently to movies, no direct effects were found (1982, p. 4; 1985, p. 121). But Dysinger and Ruckmick, in the very quotation Wartell and Reeves employ, strongly imply that direct effects do exist within the different age groups. They state, in one example, that for those above thirteen, "there was usually a definite response" $(1982$, p. 4). Indeed, in every instance Wartella and Reeves refer not to individuals, but to social groups. They classify children according to age and show that similar age groups are affected in the same way by a given message (Reeves \& Wartella, 1982, pp. 6-9). Is this a hypodermic theory? Wartella and Reeves obviously do not think so. Others disagree.

Katz and Lazarsfeld's characterization of the past as a period of direct effects recognized that a variety of audiences were presumed. They wrote that the traditional division of research into audience analysis, content analysis, and effect analysis "is misleading because it obscures the fact that, fundamentally, all of communications research aims at the study of effect" (1955, p. 18). Though they denigrate the division, they reveal that their concept of direct effects allowed for adaptation of the message to specific audiences. Those who argue that Lasswell assumed a hypodermic model also grant that he did not see the audience merely as one mass. He described successful propaganda as the strategic adaptation of a message to particular "conditions," one of which was the audience (1970, p. 185), and in a paraphrase of Aristotle he encouraged the propagandist "to cultivate the habit of identifying himself imaginatively with the subjects to be influenced, and to explore all the possible avenues of approach to their attention" (p. 210). One might identify oneself with different audiences and construct different messages for each, but a hypodermic model is still assumed to be in effect.

One fundamental disagreement between the pro and anti-hypodermic stances, then, concerns what type of audience must be assumed within a hypodermic model. Pro-hypodermic scholars generally allow for different, even divergent, audiences. Different needles with different doses and types of medications are inserted into the diverse bodies, but a direct effect, nevertheless, is achieved. The stimulus-response framework of the hypodermic model is maintained. For the anti-hypodermic school, a multiplicity of audiences is anathema to a true hypodermic model. Unless one needle can be inserted into one amalgamated mass, no hypodermic model exists. They can therefore view their emphasis on diverse audiences as a break from the received tradition, and they can question that tradition's validity. Even reference to the early sociological theories of Comte, Spencer, Tonnies, and the like, are 
problematic; they can be read as emphasizing a variety of masses rather than one unified mass.

A second, though related, topic of disagreement concerns the role of intervening or mediating variables in a hypodermic model. Advocates for the anti-hypodermic view propose that a hypodermic model must exclude any such variables. Both Wartella and Reeves (1985, pp. 120-122; also see Reeves \& Wartella, 1982, p. 10), and Chaffee and Hochheimer (1985, p. 285) cite the intervening variables examined in the Payne Fund studies as evidence that those studies did not correspond to the received tradition's hypodermic model of mass communication. The Yale studies conducted by Carl Hovland are also noted to consider mediating variables (Chaffee \& Hochheimer, 1985, p. 285). Audience members' intelligence, previous knowledge, and experience, as well as the nature and credibility of the communicative source, were among the influential factors studied by Hovland (Hovland, Janis, \& Kelley, 1953, pp. 13-14; Hovland, Lumsdaine, \& Sheffield, 1949, pp. 9-10). Lasswell also is used to argue that people are significantly influenced by propaganda and a variety of personality variables (Chaffee \& Hochheimer, 1985, pp. 285-286). Because this evidence implies the unlikelihood of direct effects, it is said to contradict the assumptions of the hypodermic model.

The pro-hypodermic alternative is to see intervening variables as elaborations of the hypodermic model, rather than as constituents of a new model. DeFleur (1966) writes that the early scholars, despite how they are characterized by Katz and Lazarsfeld, had "very definite assumptions about what was going on in between" the stimulus and response (p. 115). He nevertheless considers those studies to assume a hypodermic model. The introduction of variables "between the stimulus side of the S-R equation and the response side" simply modifies the initial theory (DeFleur \& Ball-Rokeach, 1982, p. 162). Thus while anti-hypodermic scholars argue that the Payne Fund studies are inconsistent with a hypodermic model because they examine intervening variables, their pro-hypodermic antagonists (for example, Tudor, 1974, p. 94) cite those same studies to defend the received history of direct effects.

Kline (1972, p. 23) examines Hovland's Yale studies, but reaches a conclusion diametrically opposed to that of the anti-hypodermic school:

Personality characteristics such as self-esteem, authoritarianism, other-directedness, as well as physiological attributes such as sex differences were systematically examined. Throughout this program, the learning theory model, often referred to as the 'hypodermic model' was used to examine the individual as affected by the communication.

Kline thus asserts that the hypodermic model can include intervening variables. The message may have to be adapted for those variables, but the model still holds true.

Slack and Allor (1983) emphasize the point made above. "Often what have been presented as alternatives to the hypodermic model," they state (p. 213), "have merely been elaborations." Contemporary research shows increased sophistication in the addition of intervening variables, but "sender, message, receiver, and effect" are still conceptualized as "isolatable phenomena, related to one another in single and direct relationships" (p. 213). Those variables which anti-hypodermic scholars say belie the stimulus-response pattern characteristic of the hypodermic model are asserted by pro-hypodermic scholars to fit neatly into that very model.

Clearly, very different conceptions exist of the hypodermic model. These different conceptions both result from and influence one's interpretation of mass communica- 
tion's history, one's choice of historical and critical evidence, one's view of current studies, and, most importantly, one's theoretical and methodological choices. Perhaps the significant question in mass communication at present is whether scholars today operate under the premises of the hypodermic model.

\section{THEORETICAL AND METHODOLOGICAL IMPLICATIONS}

This debate over the history of mass communication research and the shape of the hypodermic model is important for many reasons, some of which I have already detailed. But questions about the extent to which scholars today embrace the hypodermic model's premises highlight what is perhaps the most important concern: the ways in which these differing conceptions of history and the hypodermic model influence theoretical and methodological choices.

To broach this issue, let us consider some implications of the pro-hypodermic argument which states that the contemporary effects research which began with Katz and Lazarsfeld, though it recognizes intervening variables, is consistent with a hypodermic model of mass communication. Gitlin argues that when Katz and Lazarsfeld found fifty-eight percent of public affairs opinion changes to be "very often, dependent upon the mass media," they actually discredited their own two-step flow theory and, despite their assertions to the contrary; confirmed "the old 'hypodermic' notion" (1978, p. 219). Ewen (1983) and White (1983) both hold that current research perspectives, in White's terms (p. 296), "presuppose a passive audience manipulated by a medium." In this view current research does not break from the past, as Katz and Lazarsfeld asserted, but maintains a tradition which presumes mass communication to be one-directional and linear.

This conception means, first, that current mainstream research assumes a limited theoretical and methodological orientation toward effects. An effect is conceived, states Gitlin, as "a short-term 'attitude change' or a discrete behavior; or, more exactly, the report of such 'change' or behavior by a respondent" (1978, p. 214). If no change is reported in attitudes or behaviors, people are presumed not to be influenced. Gitlin's charge is directed specifically against Katz and Lazarsfeld. But if current research practices maintain the same stimulus to response conception of the communication process, as pro-hypodermic scholars claim, then the charge is generalizable.

Slack and Allor attribute this limited conception of effects to "a commitment to a conception of communication as a contextless process" (1983, p. 213). They assert that mainstream mass communication research perpetuates the hypodermic tradition, and that "the addition of mediating elements" continues to explain communication "in simple linear terms." This conception, they argue (p. 213), "seriously limits the ways in which social context can be seen as determining the nature of communication." For some in the pro-hypodermic school, then, the implications of an anti-hypodermic history are theoretically and methodologically limiting. They involve, ironically, an acceptance of the refuted tradition's hypodermic model, and the consequent exclusion of ideological concerns in favor of a one-directional linear model suited to the study of effects.

Pro-hypodermic scholars can also cite their history of mass communication research to justify their own theoretical and methodological commitments. Slack and Allor, for example, do not stop with their critique of mainstream research. They argue further that their critical orientation does not "conceptualize the sender, 
message, and receiver as simply isolatable elements of the communication process" (p. 214). Because their theoretical system describes mass communication as connected to and intertwined with various social formations-like the state, the family, and educational institutions-they define communication not in terms of its effects on individuals, but in terms of its "effectivity" in "the exercise of social power" (p. 215), or in "maintaining, enhancing, or disrupting the social formation" (p. 214). Slack and Allor's pro-hypodermic view of history enables them to claim that the critical perspective is a break from tradition, while mainstream research is not.

Slack's book (1984) exemplifies this position even more clearly. She traces common theoretical presumptions about communication technologies back to the mass society theories from which the hypodermic model sprang (pp. 45-46). Her conclusion, not surprisingly, is that "the assumption of direct and unmediated effects of autonomous, isolated technologies abounds in studies of communication technologies" (p. 56). Slack then pits her concept of structural causality against the hypodermic theories of causality that have characterized research in this area.

Other critical theorists make this same type of argument. Hall asserts the importance of his theoretical and methodological commitments by posing them against the hypodermic presumptions of "mainstream pluralism" (1982, pp. 62-65). And Grossberg's (1984) assessment of Marxist cultural interpretation claims sophistication for discursive approaches by contrasting them with classical approaches which presume a text to influence an audience directly.

The discussion above provides examples of how a pro-hypodermic history has theoretical and methodological implications. Similar examples from the antihypodermic school can be cited. I have argued in this paper, for example, that an anti-hypodermic history tends to imply an empirical orientation. Delia discusses at length how the mainstream orientation excludes or marginalizes other approaches to communication study in general, but his comments are especially relevant for the field of mass communication (1987, pp. 69-73).

The struggle over the past described in this paper, then, can in many cases be seen as an attempt to justify particular theoretical and methodological commitments. Chaffee and Hochheimer, and Wartella and Reeves argue that they represent a break from tradition, that their modes of study merit a particular claim for sophistication. Their rendition of history "is important," they state, "because it gives us a sense of how complete and adequate our answers are" (Reeves \& Wartella, 1982 , p. 4). Critical theorists, however, argue that the anti-hypodermic account of history fails to highlight a larger concern. While it leads one to ponder the answers given by contemporary effects research, critical theorists are more concerned with the completeness and adequacy of the questions posed by the effects paradigm. They assert that while contemporary effects models are perhaps more sophisticated than a simple stimulus-response, they do not break from the hypodermic theory. If the hypodermic model can exist with intervening variables, then Katz and Lazarsfeld maintained the very tradition which they condemned, as do many others today.

\section{CONCLUSIONS: HISTORY AND THE HYPODERMIC MODEL}

I want to reflect briefly on two of this paper's central concerns. This section contains some final thoughts on the view of history assumed in this paper, and suggests a resolution to the particular historical problem I have studied.

Early in this paper I asserted that history is neither a process couched in 
objectivity, nor a simple record of past events and ideas. History, rather, is a human construction; it is the systematic organization of evidence that, on its face, may seem quite disparate. The most helpful and appropriate way to judge the accounts discussed above, therefore, is not by a criterion of accuracy, though that is important, but primarily by the degree of adequacy with which they explain mass communication. Stuart Hall indirectly suggests this criterion of adequacy:

One-sided explanations are always a distortion. Not in the sense that they are a lie about the system, but in the sense that a "half-truth" cannot be the whole truth about anything. ... The falseness therefore arises . . . in the sense that it is an inadequate explanation of a process. $(1983$, p. 73 )

Insofar as no total account can be given, any explanation is subject to this criticism. What is needed is an account with a circumference broad enough to allow for a variety of explanations, and a variety of ways to understand and to study mass communication.

A relevant question, then, is which historical account provides the broadest base from which to develop and to evaluate theories of mass communication? The answer to that question provides the criterion by which the dispute over the hypodermic model's place in mass communication research can be resolved. For me, the answer is that account which considers the widest range of historical and social forces; that is, the account which recognizes the influence of mass society theory on early mass communication research, and significantly, sees most current research as an elaboration of the hypodermic model tradition. That view is most adequate, I think, because it best explains the pattern in which mass communication theory and research have developed. It accounts for the overarching similarity of the most influential studies. Recognition of this essential similarity prepares one to understand how contemporary work either continues within or diverges from the established tradition. Perhaps this will alleviate misunderstandings that result from diverse ideological and theoretical standpoints.

Of particular importance is the recognition that mass communication's assumed history and assumed conceptual roots are a significant influence upon how, what, and why media scholars study. Indeed, the field's history is of political and ideological importance. Hall (1983) asserts that "historical connections define the ways in which the ideological terrain of a particular society has been mapped out" ( $p$. 81 ). This is no less true for the society of mass communication scholars than it is for society in general. The history one embraces influences whether one studies cultural and hegemonic power, as pro-hypodermic scholars tend to do, or behavioral and attitudinal effects, as anti-hypodermic scholars tend to do. One's sense of history helps establish which questions and issues one sees as important.

George Comstock identifies three problems that confront the field of mass communication:

The problems are parochialism-the readiness to counterpose different 'approaches' as if they give different answers to the same question instead of answers to different questions; timidity-the disinclination to think the 'unthinkable' ... and rigidity-the disregard of the scientific axiom that today's 'knowledge' may be tomorrow's ignorance. (1983, p. 46)

The view of this field's history that I propose here can help to resolve these issues. First, it suggests a tradition that clarifies when answers are at odds and when questions are different. Second, it affirms the right to question the established history and established theories, as well as innovative ideas. And third, it recognizes that our 
knowledge about mass communication is based on assumptions and commitments and is not set in stone for all time. This view will not reconcile the field, but it can provide premises for understanding the multiplicity of perspectives on mass communication.

\section{NOTES}

'DeFleur's original work was published in 1966. His text is now in a fourth edition (1982) and is co-authored with Sandra J. Ball-Rokeach. Chapter seven of the fourth edition (pp. 143-165), "Mass Society and the Beginnings of Media Theory," contains much of the same material as the earlier work to which I refer. Others who, like DeFleur, argue that early mass communication research was influenced by mass society theory include Brown (1970), Hall (1982), and Mosco (1984).

${ }^{2}$ For convenience, in the remainder of this essay 1 will refer to those who grant an early hypodermic model as pro-hypodermic, and to those who dispute that tradition as anti-hypodermic. These terms describe the different conceptions of the past. They do not indicate whether the scholars to whom I refer approve or disapprove of the hypodermic model itself.

${ }^{3}$ Though I focus here on accounts by Chaffee and Hochheimer, and Wartella and Reeves, they are not alone in their assessments. Delia, 1987, p. 66, describes the received history as "a convenient fiction." Rowland (1983) critiques the pro-hypodermic view and offers an alternative, and Czitrom (1982) asserts that "the whole notion of a theory of mass society was something of an artificial and spurious construct, an intellectual strawman created by its opponents" (p. 136).

${ }^{4}$ Delia does assess the importance of the Chicago School (1987, pp. 30-37). But even the Chicago School, in its darker moments, reflected the assumptions of a hypodermic model. Charles Horton Cooley, for example, shared with his Chicago School colleagues an optimistic view of mass communication, but he did worry that one effect of "enlarged and accelerated communication" which would be "produced upon all except the strongest minds, appears to be a sort of superficiality of imagination, a dissipation of impulse, which watches the stream of personal imagery go like a procession, but lacks the power to organize and direct it" (1922, p. 145).

\section{REFERENCES}

Bauer, R.A., \& Bauer, A.H. (1960). America, 'mass society' and mass media. The Journal of Social 1ssues, 16, 3-66.

Berelson, B. (1954). Communication and public opinion. In W. Schramm (Ed.), The process and effects of mass communication (pp. 342-356). Urbana: University of Illinois Press.

Blumer, H. (1936). The moulding of mass behavior through the motion picture. Publications of the American Sociological Society, 29, 115-127.

Blumer, H. (1970). Movies and conduct. New York: Arno Press.

Brown, R.L. (1970). Approaches to the historical development of mass media studies. In J. Tunstall (Ed.), Media sociology (pp. 41-57). Urbana: University of Illinois Press.

Chaffec, S.H., \& Hochheimer, J.L. (1985). The beginnings of political communication research in the united states: Origins of the "limited effects" model. In E.M. Rogers \& F. Balle (Eds.), The media revolution in America and in western Europe (pp. 267-296). Norwood, NJ: Ablex.

Charters, W.W. (1970). Motion pictures and youth: A summary. New York: Arno Press.

Comstock, G. (1983). The legacy of the past. Journal of Communication, 33, 42-50.

Comte, A. (1915). The positive philosophy. (H. Martineau, Trans.). London: George Ball and Sons.

Cooley, C.H. (1922). Human nature and the social order. New York: Charles Scribner's Sons.

Coser, L.A. (1960). Comments on Bauer and Bauer. The Journal of Social Issues, 16, 78-84.

Cressey, P.G. (1934). The motion picture as informal education. The Journal of Educational Sociology, 7, 504-515.

Cressey, P.G. (1938). The motion picture experience as modified by social background and personality. American Sociological Review, 3, 516-525.

Gurran, J., Gurevitch, M., \& Woollacott, J. (1982). The study of the media: Theoretical approaches. In M. Gurevitch, T. Bennett, J. Curran, \& J. Woollacott (Eds.), Culture, society and the media (pp. 11-29). New York: Methuen and Co.

Czitrom, D.J. (1982). Media and the American mind. Chapel Hill: The University of North Carolina Press.

Davidson, J.W., \& Lytle, M.H. (1982). After the fact: The art of historical detection. New York: Alfred A. Knopf.

DeFleur, M.L. (1966). Theories of mass communication. New York: David McKay.

DeFleur, M.L., \& Ball-Rokeach, S.J. (1982). Theories of mass communication (4th ed.). New York: Longman.

Delia, J. (1987). Communication research: A history. In C.R. Berger \& S.H. Chaffee (Eds.), Handbook of communication science (pp. 20-98). Newbury Park, CA: Sage.

Dewey, J. (1929). Experience and nature. New York: W.W. Norton.

Dewey, J. (1946). The public and its problems. Chicago: Gateway Books. 
Durkheim, E (1933) The division of labor in society New York The Free Press

Ewen, S (1983) The implications of empiricism Journal of Communication, 33, 219-225

Freidson, E (1954) Communications research and the concept of the mass In W Schramm (Ed), The process and effects of mass communication (pp 380-388) Urbana, IL University of Illınors Press

Gitlin, T (1978) Media sociology The dominant paradigm Theory and Society, 6, 205-253

Grossberg, L (1984) Strategies of marxist cultural interpretation Critical Studies in Mass Communication, 1 , $392-421$

Hall, S (1982) The rediscovery of 'ideology' Return of the repressed in media studies In M Gurevitch, $T$ Bennet, J Curran, \& J Woollacott (Eds), Culture, society and the media (pp 56-90) New York Methuen and Co

Hall, S (1983) The problem of ideology-Marxism without guarantees In B Williams (Ed), Marx 100 years on (pp 57-86) London Lawrence and Wishart

Hovland, C I, Lumsdame, A A, \& Sheffield, F D (1949) Experiments on mass communication Princeton Princeton University Press

Hovland, C I , Janis, I L , \& Kelley, H H (1953) Communication and persuaston Psychological studies of opinton change New Haven Yale University Press

Katz, E (1960) Communication research and the image of society Convergence of two traditions The Amencan Journal of Soctology, 65, 435-441

Katz, E, \& Lazarsfeld, PF (1955) Personal influence The part played by people in the flow of mass communication Glencoe, IL The Free Press

Kındem, G , \& Teddlıe, C (1982) Film effects and ethnicity In S Thomas (Ed), Film/culture (pp 195-208) Metuchen, NJ The Scarecrow Press

Klapper, J T (1960) The effects of mass communication Glencoe, IL The Free Press

Kline, F G (1972) Theory in mass communication research In F G Kline \& P J Tichenor (Eds), Current perspectives in mass communtcation research (pp 17-43) Beverly Hills, CA Sage

Lasswell, H D (1970) Propaganda techntque in world war I Cambridge The M I T Press

Lazarsfeld, P F (1972) Qualitative analysis Boston Allyn and Bacon

Lazarsfeld, P F , Berleson, B , \& Gaudet, H (1944) The people's chorce New York Columbia University Press

Le Bon, $\mathrm{G}$ (1952) The crowd A study of the popular mind London Ernest Benn

Lowery, S , \& DeFleur, M L (1988) Milestones in mass communication research Media effects (2nd ed) New York Longman

Mead, G H (1934) Mind, self, and society Chicago University of Chicago Press

Merton, R K (1946) Mass persuaston The social psychology of a war bond drive New York Harper and Brothers

Mosco, V (1984) Home sweet factory Perspectives on mass society In S Thomas (Ed), Studies in mass communication and technology (pp 104-120) Norwood, NJ Ablex

Rowland, W D (1983) The politics of TV violence Beverly Hills, CA Sage

Reeves, B , \& Wartella, E (1982, May) For some chtldren under some conditions A history of research on children and media Paper presented at the annual meetıng of the International Communication Association, Boston

Schramm, W (1971) The nature of communication between humans In W Schramm \& D F Roberts (Eds), The process and effects of mass communication (pp 3-53) Urbana, IL University of Illinois Press

Schramm, W (1983) The unique perspective of communication A retrospective view Journal of Communication, $33,6-17$

Slack, J D , \& Allor, M (1983) The political and epistemological constituents of critical communication research Joumal of Communication, 33, 208-218

Slack, J D (1984) Communication technologies and society Conceptions of causality and the politics of technological intervention Norwood, $\mathrm{NJ}$ Ablex

Spencer, H (1969) Princtples of soczology London Archon Books

Thurstone, L L (1931) Influence of motion pictures on children's attitudes Journal of Social Psychology, 2, 291-305

Tonnes, F (1957) Communtly and society (C P Loomıs, Trans and Ed) East Lansing, MI Michigan State University Press

Trotter, W (1942) Instincts of the herd in peace and war London The Scientific Book Club

Tudor, A (1974) Image and infuence New York St Martun's Press

Wartella, E, \& Reeves, B (1982) Children and media The American research experience Paper presented at the biennial conference of the International Association for Mass Communication Research

Wartella, E , \& Reeves, B (1985) Historical trends in research on children and the media 1900-1960 Journal of Communication, 35, 118-133

Watson, J B (1913) Psychology as the behaviorist views it Psychological Review, 20, 158-177

White, R A (1983) Mass communication and culture Transition to a new paradigm Journal of Communication, $33,279-301$ 